\title{
IN MEMORIAM \\ PROF. DR. K. SNEYDERS DE VOGEL
}

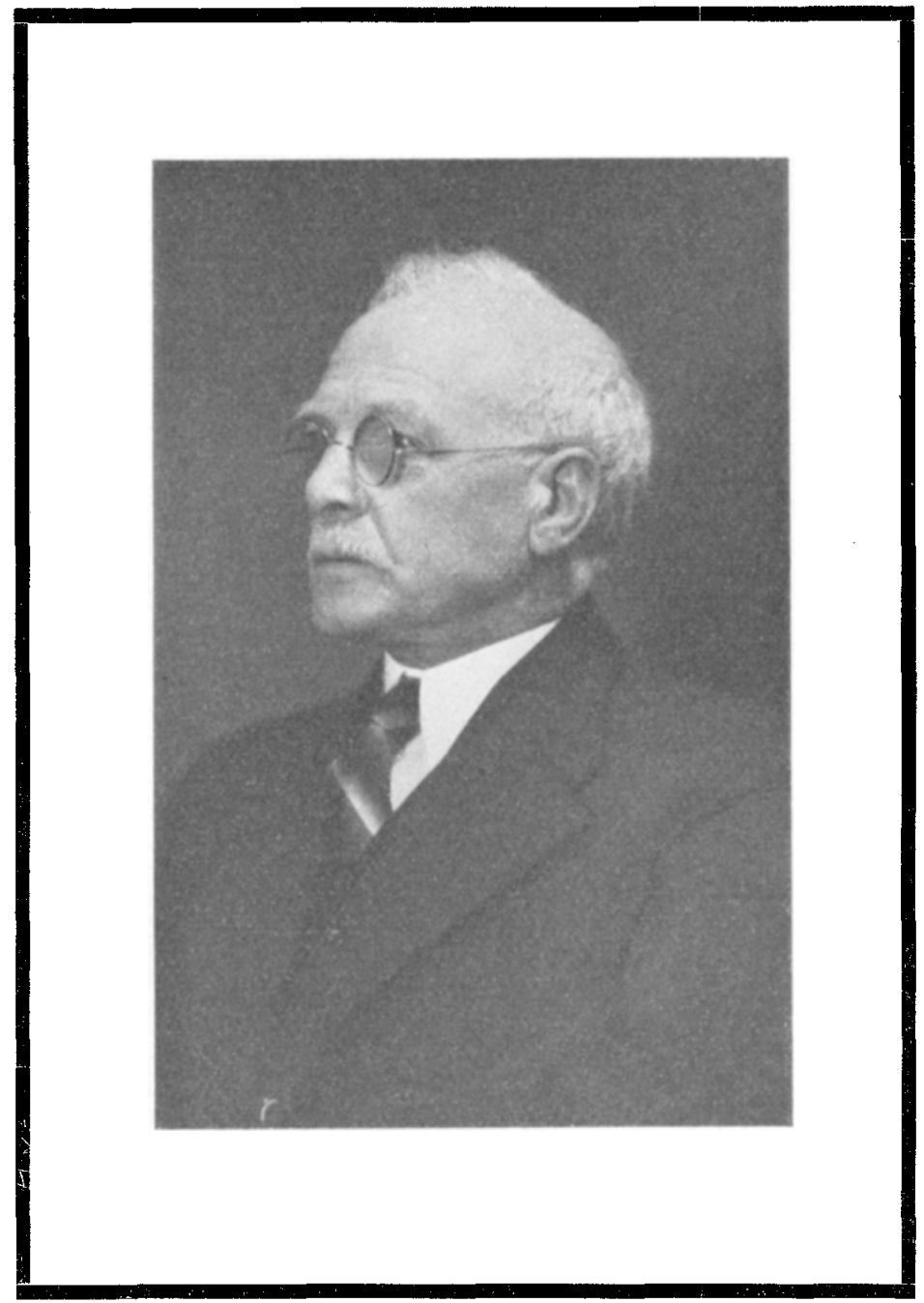

Tot onze grote droefheid overleed op 26 augustus 1958 Prof. Dr. K. Sneyders de Vogel, een van de oprichters van Neophilologus. Te zijner herdenking hopen wij in de volgende aflevering aandacht te wijden aan de bijzondere plaats, die de overledene zovele jaren in de redactie van ons tijdschrift heeft ingenomen.

De Redactie 